\section{Influence of Endodontic Sealer Composition and Time of Fiber Post Cementation on Sealer Adhesiveness to Bovine Root Dentin}

Ricardo Abreu da Rosa' ${ }^{1}$ Mirela Sangoi Barreto ${ }^{2}$, Rafael do Amaral Moraes ${ }^{2}$, Juliana Broch ${ }^{3}$, Carlos Alexandre Souza Bier², Marcus Vinícius Reis Só', Osvaldo Bazzan Kaizer ${ }^{3}$, Luiz Felipe Valandro ${ }^{3}$
'Department of Conservative Dentistry, Endodontic Area, UFRS - Federal University of Rio Grande do Sul, Porto Alegre, RS, Brazil ${ }^{2}$ Department of Stomatology, Endodontic Area, Federal University of Santa Maria, Santa Maria, RS, Brazil ${ }^{3}$ Department of Restorative Dentistry, Prosthodontic Area, Federal University of Santa Maria, Santa Maria, RS, Brazil

Correspondence: Dr. Ricardo Abreu da Rosa, Rua Gomes Carneiro, 408, 97050-470 Santa Maria, RS, Brasil. Tel: +55-55-3221-5593. e-mail: rabreudarosa@yahoo.com.br

Key Words: bond strength, endodontic sealer, fiber post, root canal filling, root dentin.

\section{Introduction}

Restoration of endodontically treated teeth becomes more complex when the tooth crown is completely or partially lost. Root canal treatment is necessary to retain the restorative materials (i.e., posts, composite cores and crown) (1). Thus, fiber-reinforced composite posts (FRC) are alternatives to cast metal posts because their elastic moduli are similar to that of dentin, producing a favorable stress distribution and providing more aesthetic outcomes for anterior teeth, especially when compounded by glass fibers. Moreover, the cementation of FRC is less timeconsuming compared with the indirect approach (cast post and core). Adhesive resin cements have been recommended to improve the retention of posts. The adhesive cementation of FRC for restoring endodontically treated teeth has demonstrated positive longitudinal results (2). Some authors have attributed this success to the similarity between the mechanical properties of the various materials (postcement-dentin), which results in a homogeneous system (3).

However, the endodontic sealer may negatively affect the bond strength of fiber posts to root dentin. Some authors observed a loss of retention when eugenol-based sealers were used before post cementation with resin cements (4), while other studies found no significant difference when comparing eugenol- and non-eugenolcontaining root canal sealers in terms of post retention using a resin cement $(1,5)$. Currently, eugenol-based sealers are still widely employed in Endodontics due their long history of clinical success; however, epoxy resinbased sealers are preferred because of their satisfactory physical properties and adequate biological performance. In addition, the epoxy resin-based sealers are still closer to the ideal filling due to a significantly smaller number of gap-containing interface areas (6).

Recently, a new salicylate resin-based sealer has been launched to the market. It is a paste-paste sealer that contains mineral trioxide aggregate (MTA). It is biocompatible, radiopaque, and stimulates mineralization (7) and calcium ion release (8). According to the manufacturer, it provides easy handling and has the following physical properties: working time, $35 \mathrm{~min}$; flow capacity, $27.66 \mathrm{~mm}$; setting time, $130 \mathrm{~min}$; optical density, 77\%; and solubility, 0.1 (7). Some investigations of this compound, such as antibacterial activity (9), cytotoxicity 
(10), solubility (11) and bond strength to root dentin (12) have been undertaken. However, there is no study that assessed the influence of salicylate resin-based sealers on the bond strength of glass fiber posts to root dentin and on the time elapsed between root canal filling and post luting.

The aim of this study was to assess the influence of the endodontic sealer type and the time elapsed between root canal filling and post cementation on the bond strength of fiber posts and bovine root dentin. The tested hypotheses were as follows: (1) when FRCs are cemented immediately after root canal filling, the salicylate resin-based sealer presents a bond strength similar to that of epoxy resins and higher than that of eugenol-based sealers; (2) 15 days later, the bond strength of FRCs to root dentin is similar, irrespective of the endodontic sealer; (3) post cementation 15 days after root canal filling increases the bond strength values observed in the eugenol-based sealer group.

\section{Material and Methods}

\section{Initial Procedures}

After approval by the institutional ethics committee (Process \#23081.015314/2010-30), single-rooted bovine teeth with similar dimensions and no root defects were

with coronal root canal diameter not greater than 2 as measured with a digital caliper (Starrett 727; Starrett, Itu, SP, Brazil), were selected for the study. A sample of 60 roots was obtained.

The roots were embedded in acrylic resin (Dencrilay; Dencril, Caieiras, SP, Brazil) cylinders and the coronal portion of the canals was prepared with Gattes-Gliden drills (Dentsply Maillefer, Ballaigues, Switzerland), sizes 2, 3 and 4 at a depth of $10 \mathrm{~mm}$. Next, a size $15 \mathrm{~K}$-file (Dentsply Maillefer) was inserted to a depth of $15 \mathrm{~mm}$, and the canals were prepared according to a stepback technique up to a size $60 \mathrm{~K}$-file. The canals were irrigated with $1 \mathrm{~mL}$ of $1.0 \%$ $\mathrm{NaOCl}$ at each change of file during chemomechanical preparation, then filled with $2 \mathrm{~mL}$ of 17\% EDTA for $3 \mathrm{~min}$, flushed with $2 \mathrm{~mL}$ of $1 \% \mathrm{NaOCl}$, and dried with absorbent paper points (Dentsply Maillefer).

\section{Test Groups}

The roots were randomly allocated into 3 groups $(n=20)$, according to the type of endodontic sealer: $\mathrm{E}$ - zinc oxide eugenol-based sealer (Endofill, Dentsply Maillefer); MTAF - salicylate resin-based sealer plus MTA (MTA Fillapex; Angelus, Londrina, PR, Brazil); AH - epoxy resin-based sealer (AH Plus, Dentsply Maillefer). Each group was divided into two subgroups $(n=10)$, according to the time elapsed between root canal filling and fiber post cementation: immediate fiber post cementation ( 0 days) or 15 days after root canal filling ( 15 days). Thus, 6 test groups were formed $(n=10): E_{0}, M_{T A F}, A_{0}, E_{15}, M_{T A F}$ and $A_{15}$.

Specimens were filled with a size 60 master guttapercha cone and accessory gutta-percha cones (Dentsply Maillefer), which were adapted to the tested endodontic sealers using lateral compaction. Root canal sealers were handled according to the manufacturers' instructions.

In groups $E_{15}, M_{T A F}$, and $A H_{15}$, the specimens were sealed with a glass ionomer sealer (Vidrion R; SS White, Rio de JaneiroRJ, Brazil) after root canal filling and stored in distilled water at $37^{\circ} \mathrm{C}$. In the groups in which post cementation was performed immediately after root canal filling $\left(\mathrm{E}_{0}, \mathrm{MTAF}_{0}\right.$, and $\left.\mathrm{AH}_{0}\right)$, the filling material was partially removed with a heated instrument and then a size 4 Largo Drill (Dentsply Maillefer) completed the removal to a depth of $10 \mathrm{~mm}$. Post space was prepared with a size 3 drill from the Whitepost DC kit (FGM, Joinvile, SC, Brazil) to a depth of $10 \mathrm{~mm}$.

\section{Fiber Post Cementation}

Before post cementation, the fiber posts were cleaned with ethyl alcohol 70\% and coated with an MPS-based primer (Prosil; FGM). Root dentin was rinsed with distilled water and dried with paper points, followed by $37 \%$ phosphoric acid conditioning for $60 \mathrm{~s}$, after which the dentin was rinsed with distilled water and dried. Using a microbrush, a multi-step etch-and-rinse adhesive system (ScotchBond Multipurpose; 3M ESPE, USA) was applied onto the dentin surface as recommended by the manufacturer (dentin etching using 37\% phosphoric acid, followed by the application of the Activator ${ }^{\oplus}$, Primer ${ }^{\circledast}$ and Catalyst ${ }^{\oplus}$ agents).

The dual-cure resin cement (AllCem, FGM) was prepared, taken into the root canal with a lentulo spiral, and the fiber post was inserted in a single movement. The cement was light-cured for $40 \mathrm{~s}$ using an LED light-curing unit (Radii Cal; SDI, Melbourne, Australia), maintaining the light guide tip of the light-curing unit placed perpendicular to the post (13). A single operator performed all procedures to avoid bias.

\section{Specimen Production and Push-Out Test}

Each specimen was fixed on the metallic base of a sectioning machine (LabCut 1010; Extec Corp, Enfield, CT, USA). The first cervical slice (approximately $1 \mathrm{~mm}$ thick) was discarded due the excess of cement in that region, which could influence adhesive resistance. Three other slices per specimen (thickness: $2 \pm 0.3 \mathrm{~mm}$ ) were obtained ( $n=30 /$ group).

Each slice was positioned on a metallic device with a central opening $(\emptyset=3 \mathrm{~mm})$ larger than the canal diameter. The most coronal portion of the specimen was placed 
downward. For push-out testing, a metallic cylinder ( extremity $=0.8 \mathrm{~mm}$ ) induced a load on the post in an apical to coronal direction without applying any pressure to the cement and/or dentin. Considering that the specimens were embedded into the epoxy resin parallel to the root axis and that the specimens were sectioned perpendicular to that axis, the post was submitted to parallel pressure to the greatest extent in relation to the root axis.

The push-out test was performed in a universal testing machine (Emic DL-2000; Emic, São José dos Pinhais, PR, Brazil) at a speed of $1 \mathrm{~mm} / \mathrm{min}$. The bond strength $(\sigma)$ in $\mathrm{MPa}$ was obtained with the formula $\sigma=F / A$, where $F=$ load for specimen rupture $(\mathrm{N})$ and $A=$ bonded area $\left(\mathrm{mm}^{2}\right)$. To determine the bonded interface area, the formula to calculate the lateral area of a circular straight cone with parallel bases was used. The formula is: $A=2 \pi g(R 1+R 2)$, where $\pi=3.14, g=$ slant height, $R 1=$ smaller base radius, $\mathrm{R} 2=$ larger base radius. To determine the slant height, the following calculation was used: $\mathrm{g}^{2}=\left(\mathrm{h}^{2}+[\mathrm{R} 2-\mathrm{R} 1]^{2}\right)$, where

Table 1 . Bond strength mean values for the sealers according to time

\begin{tabular}{lc}
\hline Time & Means and standard deviations \\
\hline Immediate & $1.7 \pm 1.1 \mathrm{a}$ \\
Endofill & $1.7 \pm 0.6 \mathrm{a}$ \\
MTA Fillapex & $2.8 \pm 1.4 \mathrm{ab}$ \\
AH Plus & \\
15 days & $1.6 \pm 1.0 \mathrm{a}$ \\
Endofill & $2.5 \pm 2.2 \mathrm{a}$ \\
MTA Fillapex & $4.3 \pm 1.4 \mathrm{~b}$ \\
AH Plus &
\end{tabular}

Different letters indicate statistically significant difference at $5 \%$.

Table 2. Failure mode distribution after the push-out test for the sealers according to time

\begin{tabular}{lcccccc}
\hline Time & Ac/d & Ac/p & CC & DC & PC & M \\
\hline Immediate & & & & & & \\
Endofill & 26 & 3 & - & - & - & 1 \\
MTA Fillapex & 27 & - & - & 1 & 1 & 1 \\
AH Plus & 25 & - & - & - & - & 5 \\
15 days & 28 & - & - & - & - & 2 \\
Endofill & 27 & - & - & - & 1 & 2 \\
MTA Fillapex & 28 & - & - & - & - & 2 \\
AH Plus & $161(89.4 \%)$ & $3(1.7 \%)$ & $-(0 \%)$ & $1(0.6 \%)$ & $2(1.1 \%)$ & $13(7.2 \%)$ \\
Total &
\end{tabular}

${ }^{*} \mathrm{Ac} / \mathrm{d}=$ Adhesive at cement/dentin interface; $\mathrm{Ac} / \mathrm{p}=$ Adhesive at cement/post interface; $\mathrm{CC}=\mathrm{Cement}$ cohesive failure; $D C=$ Dentin cohesive failure; $P C=$ Post cohesive failure; $M=$ Mixed failure. $\mathrm{h}=$ section height. $\mathrm{R} 1$ and $\mathrm{R} 2$ were obtained by measuring the internal diameters of the smaller and larger base, respectively, which corresponded to the internal diameter between the root canal walls (3). These diameters and $h$ were measured using the digital caliper.

\section{Data Analysis}

Disk specimens with cohesive fracture of the fiber post or dentin were excluded from the study to avoid misinterpretation of the results, as these types of specimens would not yield the real push-out bond strength.

After the push-out testing, the mean bond strength values of the six groups $(n=10)$ were calculated and used for statistical analysis. The data were analyzed by twoway ANOVA (time for post cementation in two levels and endodontic sealer in three levels) and Tukey's test. The significance level was set at 5\%.

\section{Results}

No specimen was lost during sectioning. After testing, some post cohesive failures and dentin fractures were observed. These specimens were excluded from the pushout bond strength calculations.

The two-way ANOVA revealed that the two variables, sealer composition and time for post cementation, affected the push-out bond strength values ( $p=0.0001$ and $p=0.3030$, respectively). The interaction between groups is shown in Table 1. No significant difference was observed ( $p>0.05$ ) when posts were cemented immediately after root canal filling. However, Tukey's post-hoc test demonstrated that the epoxy resin-based group promoted higher bond strength than that of the other groups after 15 days $(p<0.05)$. Comparing the different times for the same endodontic sealer, there were no differences for any of the three tested sealers $(p>0.05)$.

Failure mode distribution is illustrated in Table 2. Adhesive failure between the cement and root dentin $(\mathrm{Ac} / \mathrm{d})$ was predominant $(89.4 \%)$, followed by mixed failures (7.2\%). Adhesive failure between the cement and post occurred in $1.7 \%$ of the specimens, while post and dentin cohesive failures represented $1.1 \%$ and $0.6 \%$, respectively. Figure 1 represents the failure modes.

\section{Discussion}

Debonding has been reported to be the primary 
failure of fiber posts (14). Additionally, the clinical longterm success of the adhesively cemented FRCs depends on chemical, mechanical and patient-related factors. Accordingly, the influence of endodontic sealers on FRC bond strength to root dentin was assessed. This study aimed to assess the influence of the type of endodontic sealer and the time of fiber post cementation after root filling on FRC adhesion to bovine root dentin. Because it is difficult to obtain single-rooted human teeth, bovine teeth are a good alternative for in vitro studies. Previous reports indicate few microscopic differences between bovine and human dentin (15). Moreover, the volume and morphology of bovine teeth are similar to those of human canines (15).

The FRCs presented similar bond strength to root dentin, irrespective of the type of endodontic sealer, when FRC cementation was performed immediately after root canal filling ( $p>0.05)$. However, the epoxy resin-based sealer promoted higher bond strengths when FRCs were cemented 15 days after root canal filling $(p<0.05)$. Thus, both the first and second hypotheses were rejected.

According to Paschal et al. (16), post retention is lower in filled canals when compared with non-filled canals, regardless of the used cement type. This fact highlights the importance of using root canal sealer when the aim is to evaluate the bond strength of fiber posts to root dentin. Thus, it seems unnecessary to include a group without root canal fillings as a control, as the bond strength values cannot be compared. Some previous reports agree with these findings $(1,5)$. Davis et al. (5) assessed the effects of two endodontic sealers (Sealapex, a non-eugenolcontaining sealer and Tubli-Seal, a eugenol-containing sealer) on the adhesion of fiber posts to root dentin, and they did not observe any changes in bond strength when the push-out test was performed 1 week after the root canal filling. The main factors responsible for removing the free eugenol were: the time elapsed between the application of root canal sealer and post cementation, the action of the drill on root dentin for post space preparation and irrigation after post preparation (5).

Other, however, studies revealed that eugenol-based sealers decrease the bond strengths of both the composite resin core build-up and the FRCs to dentin (4). Menezes et al. (4) evaluated the bond strength of fiber posts to root dentin when post cementation was performed immediately or after 7 days. Using eugenol-based sealer for root canal filling, the bond strength values were lower when post cementation was performed immediately relative to the bond strength when post cementation was performed after seven days. These results may be explained by the similar diameters of the root canal at the moment of the root canal filling ( $1.1 \mathrm{~mm}$ diameter) and after post preparation (1.5 mm diameter). In this case, only $0.4 \mathrm{~mm}$ of possible sealer-impregnated dentin was removed; however, in the present study, $0.9 \mathrm{~mm}$ of dentin was excised. These factors can explain the similar results observed in the $E_{0}$ and $E_{15}$ groups.

The polymerization reaction of resin cements for post luting and dentin adhesive agents is inhibited by the hydroxyl group in the eugenol-based sealers, which tends to block the reactivity of the radicals responsible for polymerization (17). Unlike previous reports, which found a negative influence of eugenol-based sealers on the retention of fiber posts (4) and indirect restorations (18), the present study found similar values at 0 and 15
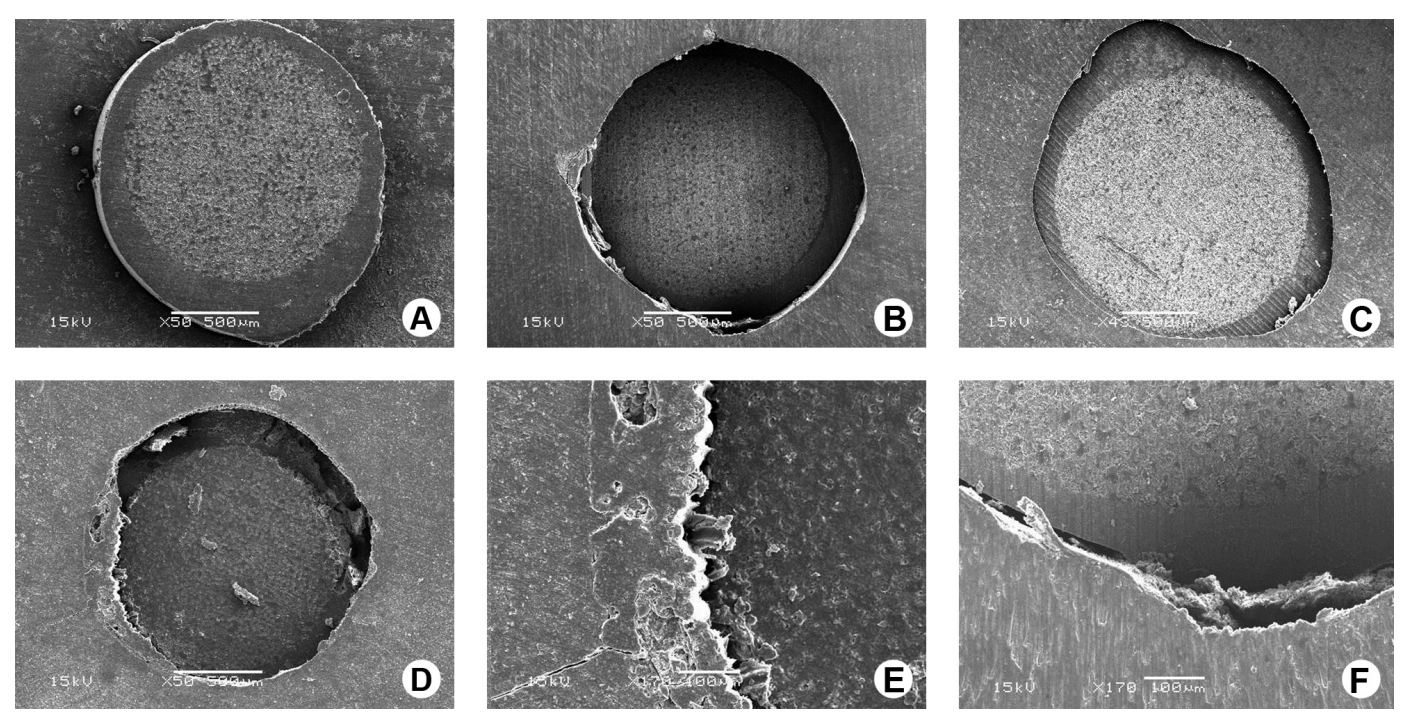

Figure 1. Failure modes. A-C: Adhesive at cement/dentin interface. D: Mixed. E: A high magnification (170x) of image 'D': adhesive at cement/post interface. F: A high magnification (170x) of image 'D': adhesive at cement/dentin interface. 
days for eugenol-based sealers. Accordingly, the third hypothesis was also rejected. This fact may be explained by the mechanical removal of the sealer-impregnated dentin from the canal walls during post space preparation.

The removal of the sealer-impregnated dentin from root canals consists of a critical step in achieving optimum post retention when resin cement is used (1). Post preparation performed after root canal filling increases the push-out bond strengths of FRCs to root dentin relative to that of roots prepared before obturation (1). A large double-tapered post ( $2.0 \mathrm{~mm}$ diameter at the cervical portion) was used to simulate clinical practice by removing the major part of the sealer-penetrated dentin during post preparation as well as to ensure an intimate fit at the post-dentin interface. Therefore, the action of the drill for canal preparation may be able of removing the eugenol-impregnated dentin, which could impair the polymerization of the adhesive and resin cement (4). Thus, as reported by Davis et al. (5), the action of the drills and the irrigant can explain the similar results observed in $\mathrm{E}_{0}$ and $\mathrm{E}_{15}$.

When sealers are introduced into the canal and obturation forces are applied, it is possible that sealer constituents penetrate into the dentinal tubules. Currently, there is a lack of information about the depth of penetration of MTA Fillapex, and further investigations must be performed. Nonetheless, the reported penetration of eugenol-based sealer does not exceed $100 \mu \mathrm{m}$ (19). However, epoxy resin-based sealers must achieve tubule penetration of up to $1,337 \mu \mathrm{m}$ (20). Due to the major tubule penetration of the epoxy resin-based sealer relative to that of eugenol-based sealer, the procedures for post cementation were not efficient in removing the sealerimpregnated dentin. Therefore, some uncured epoxy resinbased sealer $\left(\mathrm{AH}_{0}\right)$ could have remained. This process may have an important role in adhesiveness when a two-step adhesive system is used (21). Thin resin layers of these adhesives may generate great amounts of uncured acidic monomers, which results in a resin that is not completely cured by the presence of oxygen (22). It is well known that these monomers can adversely react with the amine catalysts present in dual cure cements, preventing/retarding the cement polymerization (21). It can be speculated that one of the three amine groups present in non-cured epoxy resin-based sealers $\left(\mathrm{AH}_{0}\right)$ could also react with these monomers, impairing the adhesion of fiber posts to root dentin when cemented immediately, such as the procedure followed for dual cure cements (21). Furthermore, after 15 days, AH Plus is completely set. This circumstance can explain the more favorable results observed with this sealer relative to its performance in immediate testing conditions, although no statistically significant differences were observed.
According to the manufacturer, MTA Fillapex is composed of resins (salicylate, diluting, natural), bismuth oxide, nanoparticulated silica, mineral trioxide aggregate and pigments. To date, little is known regarding its adhesive properties. Previous works $(12,23)$ reported higher adhesiveness to root dentin in AH Plus than in MTA Fillapex; however, no study has evaluated its influence on the adhesion between FRC and root dentin. The time for post cementation did not influence the bond strength of FRC to root dentin when root canals were filled with salicylate resin-based sealer $(p>0.05)$. Thus, the composition of salicylate resin-based sealer did not impair the adhesiveness of FRC, as the obtained bond strength values were similar to those of eugenol-based sealers in both tested times for post cementation, and they were also similar to those of epoxy resin-based sealers in immediate testing conditions.

The predominance of adhesive failures (89.4\%, Fig. 1) between dentin and cement agree with the literature, which stated that the bond strength on this interface is expected to be lower than that between fiber posts and cement (24). Most adhesive failures at the dentin/cement interface could be explained by the difficulty of controlling moisture inside the root canal, the high C-factor of the cavity and the decreased intensity of light transmission through the root. Additionally, the clinical affinity between post and cement plays an important role in bond strength (25). The low occurrence of cohesive failures (post cohesive, dentin cohesive or cement cohesive) in all experimental groups is due to the cohesive strength of the post, dentin or cement was most likely higher than the cement/dentin bond strength.

Under the experimental conditions of this study, the following conclusions can be drawn: 1. The time elapsed between root canal filling and fiber post cementation has no influence on post/root dentin adhesion; 2 . The type of endodontic sealer may influence the adhesion. After 15 days, the epoxy resin-based sealer promoted higher bond strength values between the FRC and root dentin than did salicylate resin- and eugenol-based sealers.

\section{Resumo}

Este estudo objetivou avaliar a influência do tipo de cimento endodôntico (um cimento à base de resina de salicilato e dois cimentos endodônticos) e do tempo decorrido entre a obturação do conduto e a cimentação do pino de fibra na adesão de pinos de fibra à dentina radicular bovina. Sessenta dentes bovinos foram divididos em seis grupos $(n=10)$, considerando um desenho experimental de dois fatores $(3 \times 2)$ : cimento endodôntico em três níveis [à base de resina epóxica (AH Plus), eugenol (Endofill) e resina de salicilato e MTA (MTA Fillapex)] e o tempo para cimentação em dois niveis (cimentação imediata e 15 dias pós a obturação). Após cimentação do pino de fibra, fatias com $2 \mathrm{~mm}$ de espessura foram obtidas e submetidas ao teste de push-out. Os padrões de falha foram analisados em estereomicroscópio $(40 \times)$ e classificados em: adesiva na interface cimento/dentina, adesiva cimento/pino, coesiva do cimento, coesiva do pino, coesiva da dentina e mista. Os dados foram analisados através dos 
testes de ANOVA a dois fatores e post hoc de Tukey $(\alpha=0,05)$. Quando os pinos de fibra foram cimentados imediatamente após a obturação dos condutos, a resistência adesiva foi similar, independentemente do tipo de cimento endodôntico. Entretanto, após 15 dias, os dentes obturados com cimento resinoso à base de resina epóxica apresentaram os maiores valores de resistência adesiva $(p<0,05)$. Os valores de resistência adesiva do mesmo cimento nos diferentes tempos experimentais não foram alterados. 0 principal tipo de falha foi adesiva na interface cimento/ dentina (89,4\%). 0 tempo decorrido entre a obturação dos condutos e a cimentação do pino não influenciou a adesão do pino de fibra à dentina radicular. Por outro lado, o tipo de cimento endodôntico influencia a adesão entre dentina radicular e pinos de fibra.

\section{References}

1. Boone KJ, Murchison DF, Schindler WG, Walker WA 3rd. Post retention: The effect of sequence of post-space preparation, cementation time, and different sealers. J Endod 2001;27:768-771.

2. Piovesan EM, Demarco FF, Cenci MS, Pereira-Cenci T. Survival rates of endodontically treated teeth restored with fiber-reinforced custom posts and cores: A 97-month study. Int J Prosthodont 2007;20:633639.

3. Bottino MA, Baldissara $P$, Valandro LF, Galhano GA, Scotti R. Effects of mechanical cycling on the bonding of zirconia and fiber posts to human root dentin. J Adhes Dent 2007;9:327-331.

4. Menezes MS, Queiroz EC, Campos RE, Martins LM, Soares CJ. Influence of endodontic sealer cement on fiberglass post bond strength to root dentine. Int Endod J 2008;41:476-484.

5. Davis ST, O'Connell BC. The effect of two root canal sealers on the retentive strength of glass fibre endodontic posts. J Oral Rehabil 2007;34:468-473.

6. Cavenago BC, Duarte MA, Ordinola-Zapata R, Marciano MA, CarpioPerochena $A E$, Bramante $C M$. Interfacial adaptation of an epoxy-resin sealer and a self-etch sealer to root canal dentin using the System $B$ or the single cone technique. Braz Dent J 2012;23:205-211.

7. Gomes-Filho JE, Watanabe S, Lodi CS, Cintra LT. Rat tissue reaction to

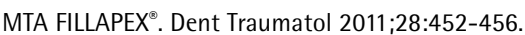

8. Kuga MC, Campos EA, Viscardi $P H$, Carrilho $P Z$, Xaviér FC, Silvestre NP. Hydrogen ion and calcium releasing of MTA Fillape ${ }^{\circledR}$ and MTA-based formulations. RSBO 2011;8;271-276.

9. Morgental RD, Vier-Pelisser FV, Oliveira SD, Antunes FC, Cogo DM, Kopper PM. Antibacterial activity of two MTA-based root canal sealers. Int Endod J 2011 44;1128-1133.

10. Scelza $M Z$, Linhares $A B$, da Silva $L E$, Granjeiro JM, Alves GG. A multiparametric assay to compare the cytotoxicity of endodontic sealers with primary human osteoblasts. Int Endod J 2012;45:12-18.

11. Borges RP, Sousa-Neto MD, Versiani MA, Rached-Júnior FA, De-Deus $G$, Miranda $C E$, et al.. Changes in the surface of four calcium silicatecontaining endodontic materials and an epoxy resin-based sealer after a solubility test. Int Endod J 2012;45:419-428.
12. Sagsen $B$, Ustün $Y$, Demirbuga $S$, Pala K. Push-out bond strength of two new calcium silicate-based endodontic sealers to root canal dentine. Int Endod J 2011;44:1088-1091.

13. Miguel-Almeida $\mathrm{ME}$, Azevedo $\mathrm{ML}$, Rached-Júnior $\mathrm{FA}$, Oliveira $\mathrm{CF}$, Silva $R G$, Messias DC. Effect of light-activation with different lightcuring units and time intervals on resin cement bond strength to intraradicular dentin. Braz Dent J 2012;23:362-366.

14. Wegner PK, Freitag S, Kern M. Survival rate of endodontically treated teeth with posts after prosthetic restoration. J Endod 2006;32:928-931.

15. Camargo CHR, Siviero M, Camargo SEA, de Oliveira SH, Carvalho CA, Valera MC. Topographical, diametral, and quantitative analysis of dentin tubules in the root canals of human and bovine teeth. J Endod 2007;33:422-426.

16. Paschal JE Jr, Burgess JO, Robbins JW. Post retention with and without root canal fillers. J Dent Res 1997;(Spec Issue):76-412.

17. Paul SJ, Scharer P. Effect of provisional cements on the bond strength of various adhesive bonding systems on dentine. J Oral Rehabil 1997;24:8-14.

18. Fonseca RB, Martins LR, Quagliatto PS, Soares CJ. Influence of provisional cements on ultimate bond strength of indirect composite restorations to dentin. J Adhes Dent 2005;7;225-230.

19. De Deus G, Gurgel-Filho ED, Maniglia-Ferreira C, Coutinho-Filho T. The influence of filling technique on depth of tubule penetration by root canal sealer: a study using light microscopy and digital image processing. Aust Endod J 2004;30:23-28.

20. Mamootil K, Messer HH. Penetration of dentinal tubules by endodontic sealer cements in extracted teeth and in vivo. Int Endod J 2007;40:873881.

21. Cheong C, King NM, Pashley DH, Ferrari M, Toledano M, Tay FR. Incompatibility of self-etch adhesives with chemical/dual cured composites: two-step vs one-step systems. Oper Dent 2003;28:747755.

22. King NM, Tay FR, Pashley DH, Hashimoto M, Ito S, Brackett WW, et al.. Conversion of one-step to two-step self-etch adhesives for improved efficacy and extended application. Am J Dent 2005;18:126-134.

23. Nagas E, Uyanik MO, Eymirli A, Cehreli ZC, Vallittu PK, Lassila LV, et al.. Dentin moisture conditions affect the adhesion of root canal sealers. $J$ Endod 2012;38:240-244.

24. Bitter K, Paris S, Pfuertner C, Neumann K, Kielbassa AM. Morphological and bond strength evaluation of different resin cements to root dentin. Eur J Oral Sci 2009 117;326-333.

25. Pest $L B$, Cavalli G, Bertani P, Gagliani M. Adhesive post-endodontic restorations with fiber posts: push-out tests and SEM observations. Dent Mat 2002;18:596-602.
Received December 19, 2012 Accepted April 2, 2013 